\title{
ДОСЛІДЖЕННЯ АМІНОКИСЛОТ CENTAUREA CYANUS L.
}

Вступ. Терапевтичне використання амінокислот є перспективним напрямком сучасної фармації та медицини. Амінокислоти відіграють важливу роль у комплексній фрармакологічній дії лікарських засобів рослинного походження, а також покращують засвоєння інших біологічно активних речовин та потенціюють їх фрармакологічну активність.

Мета дослідження - вивчити якісний склад амінокислот і визначити їх вміст у траві та квітках волошки синьої.

Методи дослідження. Амінокислотний склад сировини волошки синьої вивчали методом іонообмінної рідинно-колонкової хроматографої на автоматичному аналізаторі амінокислот ААA T-339М.

Результати й обговорення. У результаті дослідження у траві та квітках волошки синьої ідентиоріковано по 18 амінокислот, загальний вміст яких становив 4,77 мг/100 мг і 5,41 мг/100 мг відповідно. У квітках волошки синьої містилось 31,34 \%, у траві-25,70 \% незамінних амінокислот від суми амінокислот. У траві серед замінних амінокислот за вмістом переважали пролін (0,94 мг/100 мг), глутамінова (0,70 мг/100 мг) та аспарагінова (0,64 мг/100 мг) кислоти, серед незамінних - лейцин (0,27 мг/100 мг) $i$ лізин (0,24 мг/100 мг). У квітках домінуючими за вмістом замінними кислотами були аспарагінова (0,82мг/100 мг), глутамінова (0,68 мг/100 мг) та пролін (0,53 мг/100 мг), незамінними -лізин (0,46 мг/100 мг), лейцин (0,36 мг/100 мг) і треонін (0,28 мг/100 мг).

Висновки. Уперше вивчено якісний склад і визначено кількісний вміст амінокислот у траві та квітках волошки синьої, заготовлених у Харківській області. Дослідження проводили методом іонообмінної рідинно-колонкової хроматографрії. Встановлено, що незначна перевага загальної кількості амінокислот характерна для квіток волошки синьої. В обох досліджуваних видах сировини волошки синьої спостерігали домінування замінних амінокислот (3,55-3,72 мг/100 м2), зокрема глутамінової, аспарагінової та проліну. Одержані результати можна використати при розробці критеріїв стандартизації сировини волошки синьої, а також при одержанні лікарських засобів рослинного походження на ї̈ основі багатовекторної фрармакологічної активності.

КЛЮЧОВІ СЛОВА: волошка синя; амінокислоти; іонообмінна рідинно-колонкова хроматографрія.

ВСТУП. Одним із завдань сучасної фрармації $€$ пошук рослинних джерел біологічно активних речовин для одержання безпечних та ефективних лікарських засобів і дієтичних добавок.

Перш за все увагу привертають рослини вітчизняної фрлори з досвідом використання в медицині та забезпеченою сировинною базою. До таких рослин належить волошка синя (Centaurea cyanus L.) - квітучий бур'ян, який також має багато декоративних сортів.

Волошка синя містить фрлавоноїди, антоціани, карбонові кислоти, токофероли, каротиноїди, мінеральні речовини, жирні кислоти, вуглеводи $[1,2]$.

Квітки і трава волошки синьої проявляють антиоксидантну, діуретичну, протимікробну, жовчогінну, антипроліферативну активність $[1,2]$.

(с І. Б. Пєткова, Л. М. Унгурян, Л. М. Горяча, 2020.
Терапевтичне використання амінокислот $\epsilon$ перспективним напрямком сучасної фрармації та медицини $[3,4]$.

Амінокислоти $€$ первинними продуктами обміну речовин у рослинах. Вони беруть участь у синтезі протеїнів, нуклеїнових кислот, ензимів, гормонів та інших фрізіологічно активних речовин [3-6].

Окрім фрізіологічних функцій, амінокислоти ще $є$ активними терапевтичними інгредієнтами, які застосовують у профрілактиці та лікуванні різних захворювань, зокрема нервової, серцево-судинної, травної, імунної, ендокринної систем [3-5].

Під час фрармакологічних досліджень встановлено антибактеріальну активність амінокислот відносно штамів Bacillus subtilis, Staphylococcus aureus, Staphylococcus epidermidis, 
Escherichia coli, Pseudomonas aeruginosa. Також підтверджено ефективність амінокислот у попередженні утворення біоплівок [3].

Відомо, що амінокислоти можуть екстрагуватися з лікарської рослинної сировини при одержанні лікарських фрорм і відігравати важливу роль у комплексній фрармакологічній дії лікарських засобів рослинного походження, а також покращують засвоєння інших біологічно активних речовин та потенціюють їх фрармакологічну активність [5-7].

Оскільки дані щодо компонентного складу амінокислот у сировині волошки синьої в літературі обмежені, було актуальним дослідження цієї групи біологічно активних речовин.

Мета дослідження - вивчити якісний склад амінокислот і визначити їх вміст у траві та квітках волошки синьої.

МЕТОДИ ДОСЛІДЖЕННЯ. Об'єктами дослідження були трава та квітки волошки синьої, заготовлені у фразу цвітіння у 2019 р. у Харківській області.

Амінокислотний склад сировини вивчали методом іонообмінної рідинно-колонкової хроматографії на автоматичному аналізаторі амінокислот ААА Т-339M.

Для проведення гідролізу брали близько 60,00 мг сировини, поміщали на дно пробірки 3 вогнетривкого скла, додавали 0,5 мл дистильованої води та 0,5 мл хлористоводневої кислоти концентрованої, охолоджували пробірку в рідкому нітрогені до замерзання ії̈ вмісту, відкачували з неї повітря вакуумним насосом (для попередження окиснення амінокислот) та запаювали їі. Запаяну пробірку поміщали в термостат і витримували при температурі $+106^{\circ} \mathrm{C}$ протягом 24 год.

Після гідролізу пробірку охолоджували до кімнатної температури, розкривали, вміст ії переносили у скляний бюкс і на водяній бані випаровували хлористоводневу кислоту. Потім до вмісту бюксу додавали 3-4 л деіонізованої води і повторювали процес висушування.

Одержаний зразок розчиняли в $0,3 \mathrm{H}$ літійцитратному бусрері $(\mathrm{pH} \mathrm{2,2)} \mathrm{і} \mathrm{наносили} \mathrm{на} \mathrm{іоно-}$ обмінну колонку аналізатора амінокислот.

Амінокислоти ідентисікували методом стандартних добавок. Концентрацію визначали за площиною відповідних піків [8-10].

РЕЗУЛЬТАТИ Й ОБГОВОРЕННЯ. РеЗУЛЬТАТИ дослідження амінокислотного складу трави та квіток волошки синьої наведено в таблиці.

У результаті дослідження у траві та квітках волошки синьої ідентифіковано по 18 амінокислот, загальний вміст яких становив 4,77 мг/100 мг і 5,41 мг/100 мг відповідно.

У квітках волошки синьої визначено 1,69 мг/100 мг (31,34 \% від суми амінокислот) незамінних амінокислот, серед яких за вмістом домінували лізин $(0,46$ мг/100 мг), лейцин

Таблиця - Вміст амінокислот у сировині волошки синьої

\begin{tabular}{|c|c|c|c|c|}
\hline \multirow{3}{*}{ Амінокислота } & \multicolumn{4}{|c|}{ "Вміст у перерахунку на абсолютно суху сировину } \\
\hline & \multicolumn{2}{|c|}{ трава волошки синьої } & \multicolumn{2}{|c|}{ кВіткИ волошкИ синьої } \\
\hline & $\begin{array}{c}\text { Вміст, } \\
\text { мг/100 мг }\end{array}$ & $\begin{array}{c}\text { \% від суми } \\
\text { амінокислот }\end{array}$ & $\begin{array}{c}\text { Вміст, } \\
\text { мг/100 мг }\end{array}$ & $\begin{array}{c}\text { \% від суми } \\
\text { амінокислот }\end{array}$ \\
\hline Лізин* & 0,24 & 5,08 & 0,46 & 8,46 \\
\hline Треонін $^{\star}$ & 0,20 & 4,14 & 0,28 & 5,23 \\
\hline Валін* & 0,17 & 3,58 & 0,22 & 4,06 \\
\hline Лейцин* & 0,27 & 5,70 & 0,36 & 6,71 \\
\hline Ізолейцин* & 0,11 & 2,36 & 0,18 & 3,41 \\
\hline Фенілаланін * & 0,17 & 3,58 & 0,12 & 2,14 \\
\hline Аланін & 0,28 & 5,94 & 0,37 & 6,91 \\
\hline Цистин & 0,06 & 1,32 & 0,07 & 1,25 \\
\hline Серин & 0,26 & 5,40 & 0,40 & 7,37 \\
\hline Тирозин & 0,15 & 3,11 & 0,16 & 2,95 \\
\hline Гістидин & 0,07 & 1,38 & 0,10 & 1,82 \\
\hline у-Аміномасляна кислота & 0,05 & 1,06 & 0,02 & 0,36 \\
\hline Аспарагінова кислота & 0,64 & 13,34 & 0,82 & 15,26 \\
\hline Аргінін & 0,19 & 3,92 & 0,24 & 4,39 \\
\hline Вміст незамінних амінокислот & 1,22 & 25,70 & 1,69 & 31,34 \\
\hline Вміст замінних амінокислот & 3,55 & 74,30 & 3,72 & 68,66 \\
\hline Загальний вміст амінокислот & 4,77 & 100,00 & 5,41 & 100,00 \\
\hline
\end{tabular}

Примітка. * - незамінна амінокислота. 
(0,36 мг/100 мг), треонін (0,28 мг/100 мг), валін (0,22 мг/100 мг) та ізолейцин (0,18 мг/100 мг).

Вміст незамінних амінокислот у траві волошки синьої був дещо меншим, ніж у квітках, 1,22 мг/100 мг (25,70 \% від суми амінокислот). Лейцин (0,27 мг/100 мг), лізин (0,24 мг/100 мг), треонін (0,20 мг/100 мг), валін (0,17 мг/100 мг) та френілаланін (0,17 мг/100 мг) превалювали за вмістом серед незамінних амінокислот у траві волошки синьої.

Слід зауважити, що трава волошки синьої накопичувала значну кількість проліну, глутамінової та аспарагінової кислот, частка яких від загальної суми амінокислот становила 19,79, 14,64 і 13,34 \% відповідно. У мінорній кількості в цій сировині волошки синьої визначено у-аміномасляну кислоту, цистин та гістидин.

У квітках волошки синьої в найбільшій кількості, як і у траві, також визначено пролін, глутамінову та аспарагінову кислоти, але вміст їх відрізнявся: в максимальній кількості містилась аспарагінова кислота (15,26 \% від загальної суми амінокислот), у дещо нижчій - глутамінова кис- лота (12,50 \% від суми амінокислот) і пролін (9,82 \% від суми амінокислот). Вміст у-аміномасляної кислоти був найменшим у траві серед ідентифрікованих кислот.

ВИСНОВКИ. Уперше проведено дослідження амінокислотного складу трави та квіток волошки синьої, заготовлених у Харківській області, методом іонообмінної рідинно-колонкової хроматографії. У сировині волошки синьої, яку досліджували, встановлено наявність 18 амінокислот, з яких 8 - незамінні. Незначну перевагу амінокислот визначено у квітках волошки синьої (5,41 мг/100 мг) порівняно з травою (4,77 мг/100 мг). В обох досліджуваних видах сировини волошки синьої спостерігали домінування замінних амінокислот (3,55-3,72 мг/100 мг), зокрема глутамінової, аспарагінової та проліну. Одержані результати можна використати при розробці критеріїв стандартизації сировини волошки синьої, а також при одержанні лікарських засобів рослинного походження на її основі багатовекторної фармакологічної активності.

\section{СПИСОК ЛІТЕРАТУРИ}

1. Lockowandt L. Chemical features and bioactivities of cornflower (Centaurea cyanus L.) capitula: The blue flowers and the unexplored non-edible part / L. Lockowandt, J. Pinela, Cu. Lobo Roriz [et al.] // Industrial Crops \& Products. - 2019. - No. 128. - P. 496-503.

2. Fernandes L. Borage, camellia, centaurea and pansies: Nutritional, fatty acids, free sugars, vitamin E, carotenoids and organic acids characterization / L. Fernandes, E. Ramalhosa, J. A. Pereira [et al.] // Food Research International. - 2020. - No. 132. (109070). DOI:10.1016/j.foodres.2020.109070.

3. Odia A. Therapeutic uses of amino acids / A. Odia, O. Z. Esezobor. - In book: Amino Acid - New Insights and Roles in Plant and Animal. Publisher: InTechEditors: Toshiki Asao and Md. Asaduzzaman, 2017. - P. 4-14.

4. Wu G. Amino acids: metabolism, functions, and nutrition / G. Wu // Amino Acids. -2009. - 37 (1). - P. 1-17. DOI: 10.1007/s00726-009-0269-0.

5. Дроздова И. Л. Аминокислотный состав травы икотника серого / И. Л. Дроздова, Т. И. Лупилина // Вестн. ВГУ. Серия "Химия. Биология. Фармация". 2015. - № 1. - С. 125-128.
6. Waheed E. J. Biological Activities of Amino Acid Derivatives and their Complexes a Review/E. J. Waheed, S. M. H. Obaid, A. A. S. Al-Hamdani // Research Journal of Pharmaceutical, Biological and Chemical Sciences. 2019. - 10 (2). - P. 1624-1641.

7. Кочикян А. Т. Аминокислотный состав некоторых пищевых и лекарственных растений фрлоры Армении / А. Т. Кочикян, В. Т. Кочикян, А. В. Топчян // Мед. наука Армении НАН РА. - 2011. - № 3. - С. 119131.

8. Делян Є. П. Амінокислотний склад надземних органів рослин роду Sonchus / Є. П. Делян // Фармакологія та лікарська токсикологія. -2016. - № 1 (47). C. 102-106.

9. Шиморова Ю. Е. Изучение аминокислотного состава пастернака посевного (Pastinaca sativa L.) / Ю. Е. Шиморова, В. С. Кисличенко, Л.Н.Горячая // Norwegian Journal of development of the International Science. - 2020. - № 38. - C. 42-45.

10. Іосипенко О. О. Вивчення амінокислотного складу листя кабачків / О. О. Іосипенко, В. С. Кисличенко, 3. І. Омельченко // Мед. та клініч. хімія. -2020. 22, № 2 (84). - C. 72-80. 


\section{REFERENCES}

1. Lockowandt, L., Pinela, J., Roriz Lobo, Cu., Pereira, C., Abreu, R.M.V., Calhelha, R.C., Alves, M.J., Barros, L., Bredol, M., \& Ferreira, I.C.F.R. (2019). Chemical features and bioactivities of cornflower (Centaurea cyanus L.) capitula: The blue flowers and the unexplored non-edible part. Industrial Crops \& Products, 128, 496-503.

2. Fernandes, L., Ramalhosa, E., Pereira, J.A., Saraiva, J.A., \& Casal, S. (2020). Borage, camellia, centaurea and pansies: Nutritional, fatty acids, free sugars, vitamin E, carotenoids and organic acids characterization. Food Research International, 132, 109070. DOI:10.1016/j.foodres.2020.109070.

3. Odia, A., \& Esezobor, O.Z. (2017). Therapeutic uses of amino acids. In book: Amino Acid-New Insights and Roles in Plant and Animal. Publisher: InTechEditors: Toshiki Asao and Md. Asaduzzaman.

4. Wu, G. (2009). Amino acids: metabolism, functions, and nutrition. Amino Acids, 37 (1), 1-17. DOI: $10.1007 /$ s00726-009-0269-0.

5. Drozdova, I.L., \& Lupilina, T.I. (2015). Aminokislotnyi sostav travy ikotnika serogo [Amino acid composition of gray hiccup herb.]. Vestnik VGU, Seriya: Himiya. Biologiya. Farmatsiya - Bulletin of VGU, Series: Chemistry, Biology, Pharmacy, 1, 125-128 [in Russian].

6. Waheed, E.J., Obaid, S.M.H., \&Al-Hamdani, A.A.S. (2019). Biological activities of amino acid derivatives and their complexes a review. Research Journal of Pharmaceutical, Biological and Chemical Sciences, 10 (2), 16241641.

7. Kochikyan, A.T., Kochikyan, V.T., \& Topchyan, A.V. (2011). Aminokislotnyy sostav nekotorykh pishchevykh i lekarstvennykh rasteniy flory Armenii [Amino acid composition of some food and medicinal plants of the flora of Armenia]. Meditsinskaya nauka Armenii NAN RA Medical Education of Armenia of the NAS of RA, 3, 119131 [in Russian].

8. Delian, Ye.P. (2016). Aminokyslotnyi sklad nadzemnykh orhaniv roslyn rodu Sonchus [Amino acid composition of overground organs of plant genus Sonchus]. Farmakolohiia ta likarska toksykolohiia - Pharmacology and Doctor's Toxicology, 1 (47), 102-106 [in Ukrainian].

9. Shimorova, Y.Ye., Kyslychenko, V.S., \& Horiacha, L.M. (2020). Izuchenie aminokislotnogo sostava pasternaka posevnogo (Pastinaca sativa L.) [Amino acids composition study of parsnip (Pastinaca sativa L.)]. Norwegian Journal of Development of the International Science, 38, 42-45 [in Russian].

10. Iosypenko, O.O., Kyslychenko, V.S., \& Omelchenko, Z.I. (2020). Vyvchennia aminokyslotnoho skladu lystia kabachkiv [Study of the amino acid composition of zucchini leaves]. Medychna ta klinichna khimiia - Medical and Clinical Chemistry, 22 (2), 72-80 [in Ukrainian].

\section{И. Б. Петкова ${ }^{1}$, Л. М. Унгурян ${ }^{1}$, Л. Н. Горячая ${ }^{2}$ ОДЕССКИЙ НАЦИОНАЛЬНЫЙ МЕДИЦИНСКИЙ УНИВЕРСИТЕТ ${ }^{1}$ НАЦИОНАЛЬНЫЙ ФАРМАЦЕВТИЧЕСКИЙ УНИВЕРСИТЕТ ${ }^{2}$, ХАРЬКОВ}

\section{ИССЛЕДОВАНИЕ АМИНОКИСЛОТ CENTAUREA CYANUS L.}

\section{Резюме}

Вступление. Терапевтическое использование аминокислот является перспективным направлением современной фрармации и медицины. Аминокислоты играют важную роль в комплексном фрармакологическом действии лекарственных средств растительного происхождения, а также улучшают усвоение других биологически активных веществ и потенцируют их фрармакологическую активность.

Цель исследования - изучить качественный состав аминокислот и определить их содержание в траве и цветках василька синего.

Методы исследования. Аминокислотный состав сырья василька синего изучали методом ионообменной жидкостно-колоночной хроматографии на автоматическом анализаторе аминокислот $A A A$ T-339M.

Результаты и обсуждение. В результате исследования в траве и цветках василька синего идентифрицировано по 18 аминокислот, общее содержание которых составило 4,77 мг/100 мг и 5,41 мг/100 мг соответственно. В цветках василька синего содержалось 31,34 \%, в траве - 25,70 \% незаменимых аминокислот от суммы аминокислот. В траве среди заменимых аминокислот по содержанию превалировали пролин (0,94 мг/100 мг), глутаминовая (0,70 мг/100 мг) и аспарагиновая (0,64 мг/100 мг) кислоты, среди незаменимых - лейцин (0,27 мг/100 мг) и лизин (0,24 мг/100 мг). В цветках доминирующими по содержанию заменимыми аминокислотами были аспарагиновая (0,82 мг/100 мг), глутаминовая (0,68 мг/100 мг) и пролин (0,53 мг/100 м2), незаменимыми - лизин (0,46 мг/100 мг), лейцин (0,36 мг/100 мг) и треонин (0,28 мг/100 мг).

Выводы. Впервые изучено качественный состав и определено количественное содержание аминокислот в траве и цветках василька синего, заготовленных в Харьковской области. Исследование проводили методом ионообменной жидкостно-колоночной хроматографии. Установлено, что незначительное преимущество общего количества аминокислот характерно для цветков василька синего. В обоих исследуемых видах сырья василька синего наблюдали доминирование заменимых аминокислот $(3,55-$ 
3,72 мг/100 мг), в частности глутаминовой, аспарагиновой и пролина. Полученные результаты можно использовать при разработке критериев стандартизации сырья василька синего, а также при получении лекарственных средств растительного происхождения на его основе многовекторной фрармакологической активности.

КЛЮЧЕВЫЕ СЛОВА: василек синий; аминокислоты; ионообменная жидкостно-колоночная хроматография.

\author{
I. B. Pietkova ${ }^{1}$, L. M. Unhurian ${ }^{1}$, L. M. Horiacha ${ }^{2}$ \\ ODESA NATIONAL MEDICAL UNIVERSITY ${ }^{1}$ \\ NATIONAL UNIVERSITY OF PHARMACY², KHARKIV
}

\title{
STUDY OF AMINO ACIDS CENTAUREA CYANUS L.
}

\section{Summary}

Introduction. Therapeutic use of amino acids is a promising area of modern pharmacy and medicine. Amino acids play an important role in the complex pharmacological action of herbal medicines, as well as improve the absorption of other biologically active substances and potentiate their pharmacological activity.

The aim of the study - to learn the qualitative composition of amino acids and determine their content in the herb and flowers of blue cornflower.

Research Methods. The amino acid composition of raw blue cornflower was studied by ion-exchange liquid column chromatography on an automatic amino acid analyzer AAA T-339M.

Results and Discussion. As a result of the study, 18 amino acids with a total content of $4.77 \mathrm{mg} / 100 \mathrm{mg}$ and $5.41 \mathrm{mg} / 100 \mathrm{mg}$, respectively, were identified in herb and flowers of blue cornflower. Blue cornflower flowers contained $31.34 \%$, herb $-25.70 \%$ of essential amino acids from the sum of amino acids. Among the essential amino acids in the herb, proline $(0.94 \mathrm{mg} / 100 \mathrm{mg})$, glutamic $(0.70 \mathrm{mg} / 100 \mathrm{mg})$ and aspartic $(0.64 \mathrm{mg} / 100 \mathrm{mg})$ acids predominated, and leucine among the essential ones $-0.27 \mathrm{mg} / 100 \mathrm{mg})$ and lysine $(0.24 \mathrm{mg} / 100 \mathrm{mg})$. In flowers, aspartic acid $(0.82 \mathrm{mg} / 100 \mathrm{mg})$, glutamic acid $(0.68 \mathrm{mg} / 100 \mathrm{mg})$ and proline $(0.53 \mathrm{mg} / 100 \mathrm{mg})$ were the dominant substitutes for lysine $(0.46 \mathrm{mg} / 100 \mathrm{mg})$, leucine $(0.36 \mathrm{mg} / 100 \mathrm{mg})$ and threonine $(0.28 \mathrm{mg} / 100 \mathrm{mg})$.

Conclusions. For the first time, the qualitative composition and quantitative content of amino acids in the herb and flowers of blue cornflower harvested in Kharkiv region were studied. The study was performed by ion exchange liquid chromatography. It was determined that a slight advantage of the total number of amino acids is characteristic of blue cornflower flowers. In both studied raw materials, blue cornflower was found to have the advantage of substituted amino acids (3.55-3.72 mg/100 mg), in particular glutamic, asparagine and proline. The obtained results can be used in the development of criteria for standardization of raw blue cornflower, as well as in the production of drugs of plant origin on its basis of multi-vector pharmacological activity.

KEY WORDS: blue cornflower; amino acids; ion exchange liquid column chromatography. 